\title{
AN AMERICAN REMEMBERS THE CHARLES UNIVERSITY ARCHIVE IN THE ERA OF NORMALIZATION
}

\author{
GARY B. COHEN
}

Recollections of an American historian specialising in the European social history of nineteenth and twentieth century present the experiences and impressions of a 'Western' scholar, who worked in Prague archives, especially the Archive of the Charles University, in the 1970s and 1980s.

Keywords: Czechoslovakia during normalisation - foreign scholars - Archive of the Charles University - memoirs - Jan Havránek - Marie Pravdová - Karel Litsch

DOI: $10.14712 / 23365730.2018 .33$

Foreign scholars who did historical research on modern Czech and Central European history in Czechoslovak archives and libraries during the 1970s and 1980s confronted a peculiar mix of opportunities and challenges. After the August 1968 invasion by the Warsaw Treaty forces and the reversal of the Prague Spring reforms, the government undertook sweeping purges in the universities and research institutions and imposed repressive controls on intellectual and cultural life. Those policies targeted scholars in the humanities and social sciences in particular because many had supported the reform movement. The Communist Party of Czechoslovakia (KSČ) expelled large numbers of intellectuals from the Party for cause, some who were formally "vyloučen" and others who were simply crossed off the party rolls - "vyškrtnut". In general, scholars whom the Party expelled or crossed off were dismissed from teaching appointments in the universities and positions in research institutes, although a few found some partial rehabilitation. The repression largely reversed whatever opening had occurred during the middle 1960s in the tolerated range of research in the humanities and social sciences for native scholars.

After the 1968 invasion, the Czechoslovak authorities wanted to maintain the appearance of stability and normality. One result was that foreign scholars who were not working on politically sensitive topics continued to have access to nearly all the research libraries and many archival collections, whether they came to Czechoslovakia as part of officially sanctioned exchange programs or as independent scholars. Uncertainty about what historical research and publication would be tolerated and the difficult job situations for many Czechoslovak scholars worked to curtail engagement in larger research projects by many native historians and sharply reduced the number of the new Czech and Slovak scholarly books published in many fields of history for more than a decade. As a result, there were times during the 1970s and early 1980s when foreign scholars found that their numbers equaled or even exceeded the native Czech and Slovak scholars who were working in the 
same archival reading rooms on any given day. It was in these circumstances that I first arrived in Prague in September 1972 to do doctoral dissertation research on Czech-German relations in the city and the decline of the city's German-speaking minority during the second half of the nineteenth century. ${ }^{1}$

In autumn 1972, I was twenty-four years old and had never left North America previously. At that stage I had decent German and could read Czech, but had only limited spoken Czech. That first stay lasted more than nine months, and over the succeeding decade, I returned to Prague for additional research in summer 1976, summer 1981, and the first five months of 1982. The stays in 1981 and 1982 represented the initial phases of research on a second book project dealing with education and society in imperial Austria during the second half of the nineteenth century. ${ }^{2}$ The International Research and Exchanges Board (IREX), an affiliate of the American Council of Learned Societies, had formal exchange agreements with the education authorities in most of the Soviet Bloc countries; and IREX sponsored all my research in Czechoslovakia during the 1970s and 1980s, either with exchange fellowships or designation as a fellow without stipend.

Under the IREX exchange program with Czechoslovakia, when the Czech Ministry of Education accepted an American applicant, it provided formal letters of introduction to the archives and universities and certification for an extended visa. The Ministry also arranged for housing and a formal scholarly advisor for each American visitor in an appropriate university faculty or research institute.

For my initial research in Prague in 1972-1973, I was particularly fortunate that the Ministry designated as my scholarly advisors Miroslav Hroch (born 1932) and Jan Havránek (1928-2003), who was then serving as interim director of the Charles University Archive. These were ideal choices for my interests among the historians then working in Prague. During later stays, Robert Kvaček (born 1932) and Otto Urban (1938-1996) provided

1 Gary B. Cohen, The Prague Germans 1861-1914: The Problems of Ethnic Survival, Ph.D. dissertation, Princeton University, 1975; published as The Politics of Ethnic Survival: Germans in Prague, 1861-1914, Princeton University Press 1981; published in Czech translation as Gary B. CoHEN, Němci v Praze 1861-1914, Praha 2000; revised, second English edition (W. Lafayette, Indiana: Purdue University Press, 2006). This project also yielded a number of articles, including Jews in German Society: Prague, 1860-1914, Central European History 10, 1977, p. 28-54; Ethnicity and Urban Population Growth: The Decline of the Prague Germans, in: Keith Hitchins (ed.), Studies in East European Social History 2, 1981, p. 3-26; Jews in German Liberal Politics: Prague, 1860-1914, Jewish History 1/1, 1986, p. 55-74; and Deutsche, Juden und Tschechen in Prag: das Sozialleben des Alltags, 1890-1924, in: Maurice Godé - Jacques Le Rider - Françoise Mayer (eds.), Allemands, Juifs et Tcheques à Prague / Deutsche, Juden und Tschechen in Prag, 1890-1924, Montpellier 1996, p. 55-69 (Published in Czech as Němci, Židé a Češi v Praze: Společenskýživot všedního dne 1890-1914, Dějiny a současnost 20/4, 1998, p. 29-35.

2 I published the research on education and society in the book Gary B. CoHEN, Education and Middle-class Society in Imperial Austria, 1848-1918, W. Lafayette 1996; and the book chapters G. B. CoHEN, Education and Czech Social Structure in the Late Nineteenth Century, in: Hans Lemberg - Karel Litsch - Richard Georg Plaschka - György Ránki (eds.), Bildungsgeschichte, Bevölkerungsgeschichte, Gesellschaftsgeschichte in den böhmischen Ländern und in Europa: Festschrift für Jan Havránek, Vienna 1988, p. 32-45; G. B. CoHEN, Education, Social Mobility, and the Austrian Jews 1860-1910, in: Victor Karady - Wolfgang Mitter (eds.), Bildungswesen und Sozialstruktur in Mitteleuropa im 19. und 20. Jahrhundert (Studien und Dokumentation zur vergleichenden Bildungsforschung, v. 42), Cologne - Vienna 1990, p. 141-161; G. B. CoHEN, Ideals and Reality in the Austrian Universities, 1850-1914, in: Michael S. Roth (ed.), Rediscovering History: Politics, Culture and the Psyche, Stanford 1994, p. 83-101, 454-458; and G. B. CoHEN, The Politics of Access to Advanced Education in Late Imperial Austria, in Russian, in: T. M. Islamov - A. I. Miller, Avstro-Vengriia: Opyt mnogonatsional'nogo gosudarstva, Moscow 1995, p. 155-199 (also available in English as Working Paper in Austrian Studies 93-96, Center for Austrian Studies, University of Minnesota, Sept. 1993, 42 pp.). 
guidance, sharing with me their rich knowledge of Czech and Central European history and archival collections in Prague. I also consulted occasionally Josef V. Polišenský (1915-2001), Jiř́ Kořalka (1931-2015), and Zdeněk Šolle (1924-2008). The advice from all these excellent scholars was critical to the success of all my research in Czech archives and libraries.

None of the professors in the United States who advised me for the dissertation work were experts on the history of Prague, and none had never done research there. In fact, before I arrived in Prague in September 1972, I did not speak to anyone who had worked in the Czech archival collections that were relevant to my dissertation. This made getting good advice from senior Czech historians all the more important, and I was particularly lucky to be able to draw on Jan Havránek, Miroslav Hroch, Josef Polišenský, Jan Urban and Robert Kvaček for guidance. One of the delights of getting to know some of the more senior historians in Prague was being exposed to something of the old traditions of broad Central European Bildung, vzdèlání. Conversations with Havránek or with older colleagues such as Polišenský or the linguist Pavel Trost (1907-1987) ranged freely from discussions of historical archives to memoirs, belles lettres, art, music, or lore about famous local personalities and landmarks. The slower pace of change in the academic and cultural spheres in the communist lands of Central and Eastern Europe and the lesser degree of specialization among scholars in the humanities there than in Western Europe, and North America after the 1950s allowed more of the older intellectual style to survive. In many cases the heavy weight of communist controls encouraged such survivals as a reaction.

As I soon learned in fall 1972, a letter from the Ministry of Education to the Archival Administration of the Czech Ministry of the Interior or to individual archives under other ministries had enormous value in gaining speedy access to documentary collections. During the 1970s the international scholars' office of the Archival Administration in Prague was particularly efficient, thanks to the work of a veteran senior staff member, Květa Kulírová (1923-2013), who understood precisely the rules and procedures, knew many officials in the individual archives, and was committed to making sure that foreign scholars who respected the rules got the access to which they were entitled. Indeed, the quantity of documentation made available to me from those collections for the dissertation research was much more than I had expected. Even Havránek, who was a great expert on the modern history of Prague and knew the archives well, had not expected that I would find so much on Prague's German-speaking minority, since that population sank to low numbers in the last decades before World War I, and the Bohemian Governor's Office (České místodržitelství) and Prague police directorate had to devote much attention to Czech political and social groups.

Despite the general repression in the society after 1969, I generally had great success in getting the research materials I needed in all the archives and major libraries that I used. Thanks to the excellent advice and unflagging support of Havránek and his role as interim director of the university archive during my initial stays in Prague, I was able to use that institution as a base for my research activities. The bulk of my research on the German-speaking minority of Prague, in fact, took place in the Central State Archive (today called the Národní archiv, National Archive), the Prague City Archive, and the State Library in the Klementinum. Once I learned how to use the inventories and indices of the Central State Archive for documents of the former Austrian ministries, the Bohemian Governor's 
Office, the Prague police directorate, and the Prague Catholic Archdiocese, the archivists provided everything I requested. I have always attributed the good order and generally high quality of basic service in the major Czech archives to Czech traditions of efficiency and a strong work ethic and the influence of Czech national pride. The archive of the Catholic Archdiocese of Prague, held by the Central State Archive in Dejvice, had particularly good organization and finding aids, which Czech historian friends attributed to the generally good order in the Central State Archive and the fact that several devoted Catholics had responsibility for the archdiocesan papers over many years. The Prague City Archive was more difficult to use because of its location during the 1970s and 1980s in unsuitable quarters in the Clam-Gallas Palace and its thinner staffing than the Central State Archive. Having to wait for official approvals, problems in offsite storage facilities, or local construction projects in one or another archive or library delayed at times my obtaining access to particular books and documents. In the end, however, the only materials relevant to my projects which I failed to get had either been discarded or lost. Completion of orders for photocopies and microfilms was often slow, but all the copies and films that I requested were eventually produced.

One could even argue that the political controls of the "normalization" era helped sustain the quality of service in a number of archival and library collections because of the smaller number of users than might have been expected under other circumstances and the dedication of archivists who were trying to make successful, secure careers away from the more difficult circumstances of the university faculties and Academy of Sciences. A number of fine scholars, such as Jiř́ Kořalka, Zdeněk Šolle, and František Šmahel (born 1934), who lost their positions in universities or the Academy of Sciences after 1968 eventually found new work in archives and museums. Younger scholars with recent degrees, such as Ivana Čornejová (born 1950), Petr Čornej (born 1951), Jiří Pešek (born 1954), Martin Svatoš (born 1951), and Michal Svatoš (born 1947), who could not obtain normal university teaching appointments, also found work in research collections, several of these individuals in the Charles University Archive.

The neo-Stalinist tendencies of the Czechoslovak government and the vocal anti-Israel policies throughout the Soviet Bloc during the 1970s and 1980s put particular pressure on what was then the State Jewish Museum in Prague. Even with certification from the Ministry of Education and the Archival Administration, I had to wait for several months in 1973 before the Jewish Museum's director permitted me to do research in the Museum's archive. During the interim I was able to make friends with the then archivist, $\mathrm{PhDr}$. Jan Heřman (1933-1986), who was completing a major project to microfilm much of the Museum's prime archival holdings for the Central Archives for the History of the Jewish People in Jerusalem.

Surprisingly, the only other archive where I encountered any difficulty in the mid-1970s was the Charles University Archive. When I returned to Prague in 1976, I found that doc. PhDr. Marie Pravdová (1907-1982), an historian of modest scholarly accomplishment who was deeply loyal to the Communist Party, had replaced Havránek as director of the university archive. She had been brought in from the Pedagogical Faculty, while Havránek and his other colleagues remained on the archive staff. Doc. Pravdová was hostile to my doing research in the archive, and she shared with me in candid terms her nationalist antipathies to the former German-speaking minority and the former Jewish population of Bohemia 
and Moravia. She initially resisted accepting my letter of introduction from the Ministry of Education and only permitted my research in the university archive when she saw the certification of my foreign researcher status from the Archival Administration of the Ministry of Interior. Even then, she gave instructions to the university archive staff that they were to have minimal interaction with me. Fortunately for me, most of them considered Pravdová to be a primitive Stalinist and did their best to ignore such directives. Some of the staff speculated about her possible relations with the State Security Service (Státní bezpečnost, StB).

Such speculation was widespread in an era when secret police surveillance and informing were rife. In fact, during the 1970s and 1980s there were many figures like Pravdová in the Czechoslovak governmental officialdom and in the educational and archival establishments. The policies of "normalization" after the post-invasion purges kept in place many old holdovers from the 1950s, brought back others from retirement, and promoted some who had been pushed into the shadows by the reformers of the mid-1960s. ${ }^{3}$ Nonetheless, during the 1970s and early 1980s, I also encountered a number of people in responsible positions in university offices, archives, and libraries who were politicky dobrý, i.e., had good political credentials, but who still espoused good academic values, supported solid scholarly work, and treated other scholars well, whether native or foreign. An excellent example was Pravdová's successor as director of the Charles University Archive, Doc. PhDr. Karel Litsch (1929-2009), a legal historian from the Law Faculty, who was a veteran member of the KSČ and led the Party unit in the Law Faculty for a number of years.

The arrival of Litsch as director of the university archive was a breath of fresh air. $\mathrm{He}$ welcomed both native and foreign scholars who came to do research and used his secure position to support the staff's scholarly work and their professional advancement. He even permitted the holding of private historical seminars in a windowless room of the archive organized by some of the younger scholars from the staff, where they and other young historians from the Philosophical Faculty and other archives and libraries gave presentations on their research. The organizers had to exercise some caution in issuing invitations, but I attended several times during winter and spring 1982 and gave a presentation to the seminar on project on education and society in Imperial Austria.

There was risk, of course, in holding any private seminar in Prague during the era of "normalization", since the Party and police authorities could easily declare such activity subversive of proper order. One learned, though, that enforcement of such prohibitions was often inefficient and that a certain amount of porosity characterized many official restrictions, leaving room for some maneuvering by those with the necessary skills or protekce from a higher authority. To be sure, the signs and impact of repression were visible everywhere in a country where a half million people had been removed from the Party rolls after 1968 and were demoted or lost their jobs as a result. The Party also reimposed far-reaching censorship on public media and all publication activity. Copier machines were closely monitored, former leaders of the reform movement and dissidents were subjected to close surveillance, harassment, and arrest, and one always had to be wary of informers. Still,

3 On the methods and results of the purges in the Philosophical Faculty of the Charles University, for example, see Jakub JAREš - Matěj SpurnÝ - Katka Volná - Jakub Bachtí - Marta Edith HoleČKovÁ - Adam HorkÝ Klára PINERovÁ, Náměstí krasnoarmějcủ 2. Učitelé a studenti Filozofické fakulty UK v obdobi normalizace [Red Army Soldiers Square no. 2. Instructors and Students of the Philosophical Faculty of the Charles University in the era of normalization], Prague 2012, p. 51-100. 
Czechoslovak citizens complained continually about the government, the Soviet Union, and living conditions. Many knew about dissident activities, and some intellectuals circulated samizdat literature -although with caution. Officially banned goods were bought and sold, and people listened to Western radio broadcasts despite official warnings. Some retirees even took up residence near the western and southern borders in order to receive West German or Austrian television signals.

For the most part, Czechs were kind and welcoming to me in both formal and informal settings. The hospitality, support, and enduring friendship of staff members in the Charles University Archive - except for doc. Pravdová - represented a much appreciated instance of this. Havránek and his colleagues helped me to understand and interpret the unfamiliar surroundings, and they regularly informed me about important new and old books I should buy, films and museums to see, interesting sightseeing opportunities, and where to find needed consumer goods. Late, in my lecture classes at the University of Oklahoma and later at the University of Minnesota, I told with relish stories about consulting with Michal Svatoš in the Charles University Archive about where one could find fresh fruit in Prague in mid-winter or, more embarrassingly, where rolls of toilet paper could be bought when once the supply for the whole city failed for more than a week. In spring 1982, when my American dissertation advisor, Carl E. Schorske, came to Prague for the first time in his life, Havránek was able to arrange lodging for him in the guest rooms of the Charles University rectorate, where his neighbor was the visiting rector of the Moscow State University. I took special delight in showing Schorske the beauties of the city, taking him to a new production of Smetana's Dalibor during the Prague Spring music festival and a concert in the Smetana Hall, and introducing him to Havránek, Hroch, and Urban as well as several members of the Prague musical community. Altogether, Schorske's visit went beautifully; knowing some of the right people and being able to get some protekce had its benefits in communist Czechoslovakia.

For the most part, the security police subjected me to discrete surveillance. My incoming and outgoing international mail took some weeks longer to arrive during the first month of any stay than later, but everything eventually got through, including dozens of packages of books and Supraphon and Panton recordings which I sent out. No letters that I received showed obvious signs of having been opened. More often than not, my luggage and papers were thoroughly searched when I left the country by train, but not when I departed by plane. I never saw any signs that my housing had been searched, although much later I found out from reading a book about the Charles University's Philosophical Faculty during the normalization, of Náměstí krasnoarmějců 2, that my dormitory room had been searched at least once. ${ }^{4}$ Havránek and my other formal scholarly advisors at the Philosophical Faculty and at least some of the archival officials whom I saw regularly certainly had to file reports on me with the Státní bezpečnost (StB), although I never knew how often or exactly when and where that was done. Such reporting was only to be expected under the circumstances of the time, and as far as I have been able to determine, no harm ever came to me or to anyone with whom I associated because of the reports on me. I have never tried to request and read any of the security police files relating to me.

4 J. JAREŠ - M. SPURNÝ - K. VolnÁ a kol., Náměstí krasnoarmějců 2. 
As an American visitor, of course, I could freely leave Czechoslovakia and return home at the end of each research stay. My Czech colleagues and friends who did not flee the country had to live with the constant surveillance of the StB, censorship, periodic official reviews (prověrky) of their attitude and public behavior, limited opportunities for professional advancement, and an ill-functioning economy. For them the opportunity to travel even briefly outside the communist bloc was a rare privilege indeed. For most of two decades the prospects were dismal for any significant change in the domestic situation for the better. The demoralization of the population that this caused was perhaps the saddest consequence of the conditions of normalization. Only after late 1988, with the development of Gorbachev's reform policies and the disintegration of communist rule first in Poland and Hungary and then East Germany, did the outlook for my friends in the Charles University Archive and Czechs and Slovaks more generally change in any significant way.

\title{
GARY B. COHEN
}

\section{Američan vzpomíná na Archiv Univerzity Karlovy v éře normalizace}

\author{
RÉSUMÉ
}

Vzpomínková črta amerického historika sociálních dějin Evropy 19. a 20. století přináší zajímavý pohled „západního“ zahraničního badatele na realitu Československa v éře normalizace. Líčí osobní dojmy tehdy mladého amerického historika ze soudobých poměrů, popisuje řešené badatelské projekty i jejich institucionální zajištění a přibližuje nejenom tehdejší situaci československých historiků, ale především autorovy osobní zkušenosti a zážitky z pražských archivů v 70. a 80. letech 20. století. Hlavní důraz je přitom kladen na Archiv Univerzity Karlovy a jeho pracovníky, v čele s řediteli Janem Havránkem, Marií Pravdovou a Karlem Litschem. Zatímco u J. Havránka i K. Litsche autor oceňuje jejich zájem a odbornou úroveň a vyzdvihuje podporu, které se mu z jejich strany dostalo, v prŕípadě M. Pravdové konstatuje její negativní, až nepřátelský postoj.

\section{Ein Amerikaner erinnert sich an das Archiv der Karlsuniversität zur Zeit der Normalisierung}

\section{ZUSAMMENFASSUNG}

Diese Erinnerungsskizze eines amerikanischen Sozialhistorikers (Sozialgeschichte Europas des 19. und 20. Jh.) bietet einen interessanten Einblick eines ,,westlichen“ ausländischen Forschers in die Realität der Tschechoslowakei zur Zeit der Normalisierung. Geschildert werden persönliche Eindrücke dieses damals jungen amerikanischen Historikers von den zeitgenössischen Verhältnissen, beschrieben werden die bearbeiteten Forschungsprojekte und ihre institutionelle Gewährleistung, und näher gebracht wird nicht nur die damalige Lage der tschechoslowakischen Historiker, sondern vor allen Dingen die persönlichen Erfahrungen und Erlebnisse des Verfassers in den Prager Archiven der 1970er und 1980er Jahre. Dabei wird der Nachdruck vor allem auf das Archiv der Karlsuniversität und seine Mitarbeiter, allen voran ihre Direktoren Jan Havránek, Marie Pravdová und Karl Litsch gelegt. Während Verf. bei J. Havránek und K. Litsch ihr Interesse und fachliches Niveau würdigt und die Unterstützung hervorhebt, die er durch sie erfuhr, kann er im Falle von M. Pravdová nur ihre negative bis feindselige Einstellung konstatieren. 